\section{Producing Transplantable Human Tissues in the Laboratory}

The July issue of Discovery contains an article by Dr. D. Petrucci, Medical Biological Studios, Bologna, entitled "Producing Transplantable Human Tissue in the Laboratory". The article resulted from Dr. Petrucci's original work on building tissues which, in contrast to adult tissues, would be transplantable and acceptable by adult organisms. The idea was that the chances of a glandular transplant surviving would be improved if the gland were obtained from an embryo that is first cultivated outside the maternal body. The technique was to fertilize the ovum between two chamois disks, in what Dr. Petrucei calls his "biological cradle". Various 'cradles' have been used in which the developing zygote and embryo could be photographed continuously. The article is extensively illustrated, and the 48 illustrations show the fertilization and development of the embryo covering a period of 58 days of growth from fertilization; they also demonstrate the 'cradle'. In a field so sparse in workers, who themselves tend to be highly sceptical of all and everybody's work in that field, it is a pleasant relief to find a general article. The illustrations will be of great use to science teachers.

\section{Geology and Ceramics}

To mark the occasion of the Seventh International Ceramic Congress, held in London during May 1960 , a special exhibition of rocks and minerals used by the British ceramic industry was shown at the Geological Museum in South Kensington. A booklet (Geology and Ceramics. Pp. ii +28 . London: H.M.S.O., 1961. 3s. 6d. net), prepared by Dr. P. J. Adams, was issued to give a brief account of the rocks and minerals used in the industry, describing their nature and geological occurrence. The many ways in which the raw materials are used by the ceramist, potter and engineer are also described. The booklet is well illustrated and the subject-matter is dealt with under the headings of pottery and whitewars, structural clay products and refractories and technical ceramics.

\section{Announcements}

The first award of the Herbert E. Gregory Medal for distinguished service to science in the Pacific, established by the Trustees of the Bernice P. Bishop Museum, Honolulu, Hawaii, in memory of Prof. Herbert E. Gregory, director of Bishop Museum during 1919-36 and Silliman professor of geology in Yale University, was recently made at the tenth Pacific Science Congress to A. P. Elkin, emeritus professor of anthropology at the University of Sydney. Prof. Elkin is distinguished by his contribution to anthropological research in Australia and Melanesia and by his active role in the development of institutions supporting Pacific research.

Prof. Seymour S. Kety, professor of psychiatry, Johns Hopkins University, has been awarded the Alvarenga Prize by the College of Physicians of Philadelphia for his work on cerebral blood flow and the effect of drugs on the central nervous system.

Oscar A. QuiHillalt, of Argentina, has been elected president of the International Atomic Energy Agency at its recent meeting in Vienna.

Dr. J. W. Menter has been appointed director of the Tube Investments Research Laboratory at Hinxton Hall, near Cambridge. The Laboratory carries out fundamental research in metal physies and physical metallurgy. During seven years at Hinxton, Dr. Menter has directed research teams studying the microstructure of metals and has promoted notable advances in the techniques of electron microscopy and $\mathrm{X}$-ray microanalysis.

Mr. J. C. Hanbury, chairman of Allen and Hanburys, Ltd., has been elected chairman of the British Pharmaceutical Conference for 1961-62. Mr. Hanbury took the Natural Science Tripos at Cambridge and later obtained the degree of bachelor of pharmacy of the University of London. He has spent the whole of his working life with Allen and Hanburys, Ltd.

DR. W. J. BATES, lecturer in physics at the University of Bristol, has been appointed chief engineer at R. and J. Beck, Ltd. Dr. Bates will lead Beck's design team at the Lister Works, Dickenson Street, London, N.W.5. Later he and his team will move on to the Company's new factory at Watford when it is completed.

Tre Basic Science Section of the British Ceramic Society is holding a meeting on "Ceramics in Nuclear Science" at the Atomic Energy Research Establishment, Harwell, during November 28-30. Further information can be obtained from Dr. J. P. Roberts (honorary section secretary), Houldsworth School of Applied Science, University, Leeds, 2.

THE Institute of Biology is organizing a symposium on "The Better Use of the World's Fauna for Food", which will be held in the Lecture Hall, Royal Geographical Society, Kensington Gore, London, S.W.7, during October 27-28. Attendance at the symposium is open, and further information can be obtained from the Institute of Biology, 41 Queen's Gate, London, S.W.7.

A sHort course on "Chemical Applications of Diffraction Methods" is being organized by the Department of Chemical Technology, Bradford Institute of Technology, and will be held at the Institute during November 24-25. The fee for the course is $45 s$., and further information can be obtained from the Registrar, Institute of Technology, Bradford, 7.

THE autumn meeting of the Parasitology Group of the Institute of Biology is to be held at the National Institute for Medical Research, Mill Hill, London, N.W.7, on November 10. The meeting will be devoted to a series of papers under the general title of "Parasites of World Importance". Further information can be obtained from the acting secretary of the Group, L. P. Joyner, Central Veterinary Laboratory, Ministry of Agriculture, Fisheries and Food, New Haw, Weybridge, Surrey.

THE South London Branch of the British Institute of Management is organizing a second conference on the preparation and use of case studies. This is to be held at the British European Airways Staff College, East Burnham, Slough, Bucks, during October 13-15. Inquiries should be addressed to Mr. B. E. Baldrey, Conference Secretary, Palmer's Travelling Cradle and Scaffold, Ltd., : Woodside Green, London, S.E.25.

Erratim. In the article entitled "A New Test for detecting Anaphylactic Sensitivity : the Basophil Reaction", appearing on p. 1056 of the September 9 issue of Nature, the fixative solution consisted of ethyl alcohol $6 \mathrm{ml}$., chloroform $2 \mathrm{ml}$., and acetic acid $2 \mathrm{ml}$. The solution did not contain acetone as stated. 